\title{
Adluvionum ea natura est, ut semper incerta possessio sit: Picturing and Regulating Alluvial Lands in Nov. Theod. 20
}

\author{
Francesco Bono
}

Around 214 CE, Aurelius Hierax and the heirs of Aline, habitants of Hermopolis, petitioned to the basilikogrammateos of the Hermopolites. ${ }^{1}$ The petition concerned their vineyard, which was situated near the Nile. ${ }^{2}$ The river had eroded part of their property and the owners asked the official to estimate the size of the field once more because they did not want to pay taxes for the surface destroyed by the overflow of the Nile. We do not know from the papyrus whether or not the petition found favour with the magistrate and was approved, but we can be sure that such a tax-related situation was rather common in Egypt.

It is not surprising that in the Padus valley, soil erosion as a consequence of the flooding of the river caused harm to the land of landholders. Agennius Urbicus, a Roman land surveyor (gromaticus), ${ }^{3}$ mentioned that the Padus river could cause different types of damages. For example, when it left its bed, it could burst through the middle of someone's farm and create an island between its old and new course. The landholder now had a river flowing in the middle of in his land and consequently he suffered a loss of arable land. ${ }^{4}$

From Egypt to Gallia Cisalpina, rivers showed their power. In some cases, they could be destructive, in other cases, they could increase the area of arable land. Clearly, water resources involved a great number of regulations and had a great impact on the daily of Roman citizens: from the management of land and relations between neighbours, to legal disputes caused by the river's course. ${ }^{5}$

Natural phenomena, in general, were taken in consideration by Roman jurists. They seemed to be very conscious of the different ways in which water

1 On this administrative office see, D. Bonneau, Le régime administratif de l'eau du Nil dans l'Egypte grecque, romaine et byzantine (Leiden 1993), 247.

2 P. Lond. 3.934 p. XLVII. Cf. G. Bastianni, 'La corrente del Nilo', Tyche 1 (1986), 5-11.

3 G. Chouquer and F. Favory, Les arpenteurs romains. Théorie et pratique (Paris 1992); G. Chouquer, L'arpentage romain. Histoire des textes, droit, techniques (Paris 2001); B. Campbell, The Writings of the Roman Land Surveyors. Introduction, Text, Translation and Commentary (London 200o).

4 Agenn. 82.21

5 E.g. C.J. Bannon, Gardens and Neighbors: Private Water Rights in Roman Italy. (Ann Arbor 2009) and n. 6 and 10 below for further references.

(C) FRANCESCO BONO, 2022 | DOI:10.1163/9789004411449_012

This is an open access chapter distributed under the terms of the CC BY-NC 4.o license. 
modified the landscape and how many consequences resulted from the change of a river's course. Gaius, the author of the most famous introduction to Roman law, carefully describes several legal problems that rivers could create. ${ }^{6}$ For the following discussion, some definitions are needed, similar to what Gaius did. Especially the terms alluvio, avulsio, insula in flumine nata and alvei mutatio need precision. ${ }^{7}$ Not only Gaius, but also jurists in general, asked themselves the delicate question of the instability of river courses and how to translate this instability into rules of law. ${ }^{8}$

Similar to jurists, emperors paid much attention to alluvial lands. ${ }^{9}$ The Flavian emperors had initiated a very extensive revision of the cadastral system, which would then continue under the Antonini. The imperial government dealt with the problems connected to the assignment or possession of lands near the rivers and with the questions related to the registration of these lands in the cadastral plans. The problem, however, was not solved and in late antiquity such regulations would continue. It is these late-antique regulations that I have chosen to analyse. ${ }^{10}$ In particular, I will focus on Novella

6 On alluvial increments: P. Maddalena, Gli incrementi fluviali nella visione della giurisprudenza classica (Napoli 1970); L. Maganzani, 'I fenomeni fluviali e la situazione giuridica del suolo rivierasco: tracce di un dibattito giurisprudenziale', Jus 44 (1997), 34339o; L. Maganzani, 'Ripae fluminis e dissesti idrogeologici a Roma: fra indagine geomorfologica e riflessione giurisprudenziale', Jus 57 (2010), 175-193; C. Masi Doria, 'Droit e nature: inundatio, mutatio alvei et interitus rei. Un cas entre ius Romanorum et tradition romain', in M. Clavel Leveque and E. Hermon (eds.), Espaces integres et ressources naturelles dans l'empire romain (Besancon 2004), 201-218; P. Castillo Pascual, 'El rio y sus paisajes: los genera per alluvionem de agrimensores y juristas', Studia et documenta historiae et iuris 79 (2013), 221-233; S. Barbati, 'Riflessioni sull'alluvione e sugli altri fenomeni fluviali, anche a margine della riforma apportata dalla l. 37/1994', Index 43 (2014), 218-293.

7 Dig. 41.1.7pr.-5 (Gai. 2 rer. cott.), but also Gai. inst. 2.70-72 (text and translation below n. 21).

8 Dig. 6.1 .34 (Iul. 7 Dig.); Dig. 6.2.11.7 (Ulp. 16 ad Ed.); Dig. 7.1.9.1-6 (Ulp. 17 ad Sab.); Dig. 7.1.9.4 (Ulp. 17 ad Sab.); Dig. 7.1.33.1 (Pap. 17 Quaest.); Dig. 7.4.24pr. (Iav. 3 ex post. Lab.); Dig. 12.6.15pr. (Paul. 10 ad Sab.); Dig. 13.7.18.1 (Paul. 29 ad Ed.); Dig. 18.6.7pr. (Paul. 5 ad Sab.); Dig. 19.1.13.14 (Ulp. 32 ad Ed.); Dig. 21.2.15pr. (Paul. 5 ad Sab.); Dig. 21.2.64.1-2 (Pap. 7 Quaest.); Dig. 23.3.4 (Paul. 6 ad Sab.); Dig. 38.2.44.2 (Pomp. 5 Quaest.); Dig. 41.1.12pr. (Call. 2 inst.); Dig. 41.1.16 (Flor. 6 inst.); Dig. 41.1.29 (Paul. 16 ad Sab.); Dig. 41.1.3o (Pomp. 34 ad Sab.); Dig. 41.1.38 (Alf. 4 dig. a Paulo epit.); Dig. 41.1.56pr.-1 (Proc. 8 Epist.); Dig. 41.1 .65 (Lab. 6 pithanon a Paulo epit.); Dig. 41.10.2 (Paul. 54 ad Ed.); Dig. 43.12.3 pr.-2 (Paul. 16 ad Sab.); Dig. 43.12.1 (Ulp. 68 ad Ed.); Dig. 43.20.3.2 (Pomp. 34 ad Sab.).

9 Cod. Iust. 7.41.1; Cod. Iust. 7.41.2.

10 S. Barbati, 'Brevi note su natura ed effetti giuridici dell'alluvione in una lex di Teodosio II del 440', Jus 2 (2014), 349-378; S. Tarozzi, Alluvioni e paludi: strategie d'intervento dell'amministrazione tardo antica, in Ravenna capitale. Il diritto delle acque nell'Occidente tardo antico: utilità comune e intessi privati (Santarcangelo di Romagna 2018), 51-52. 
Theodosiana 20 of 21st September 440,11 an imperial epistula addressed to Cyrus, Praetorian Prefect. ${ }^{12}$

Impp. Theodosius et Valentinianus aa. Cyro praefecto praetorio et consuli designato.

Suggestionibus tui culminis semper magnum aliquid rei publicae conferendi materia ministratur, semper nobis aliquid porrigitur emendandum. Quanta itaque magnitudinis tuae provincialium cura est, per eas quoque non dubie declaratur.
Emperors Theodosius and Valentinian Augustuses to Cyrus, Praetorian Prefect and Consul Designate.

By the reports of Your Eminence the material is always afforded to Us for conferring some great advantage upon the State; something is always presented to Us for correction. It is therefore undoubtedly made manifest through these reports also how great is the solicitude of Your Magnitude for the provincials.

11 The importance of this Novella is further attested by the fact that some of its parts are inserted in the Codex Iustinianus: Cod. Iust. 7.41.3 Ea, quae per adluvionem sive in Aegypto per Nilum sive in aliis provinciis per diversa flumina possessoribus adquiruntur, neque $a b$ aerario vendi neque a quolibet peti nec separatim censeri vel functiones exigi hac perpetuo lege valitura sancimus, ne vel adluvionum ignorare vitia vel rem noxiam possessoribus videamur indicere. 1. Similiter ne ea quidem, quae paludibus antea vel pascuis videbantur adscripta, si sumptibus possessorum nunc ad frugum fertilitatem translata sunt, vel vendi vel peti vel quasi fertilia separatim censeri vel functiones exigi concedimus, ne doleant diligentes operam suam agri dedisse culturae nec diligentiam suam sibi damnosam intellegant. 2. Cuius legis temeratores quinquaginta librarum auri condemnatione coerceri decernimus: inter quos habendum est officium quoque tuae sedis excelsae, si aliquid eiusmodi suggesserit disponendum vel si preces instruxerit petitoris. Transl. by B.W. Frier: "We ordain by this perpetually valid law that property which is acquired by possessors through alluvium, whether in Egypt because of the Nile or in other provinces because of various rivers, shall not be sold by Treasury nor claimed by anyone, nor shall it be separately assessed or compelled to obligations. In this way We will not seem to overlook the defects of alluvial lands or to impose something injurious on possessors. Similarly, We do not permit even those lands formerly assigned to swamp or pasture but which have been made agriculturally productive through the outlays of possessors to be sold or claimed or separately assessed or compelled to obligation as fertile lands, lest the diligent lament the efforts they expended in cultivating them and witness their diligence turned into loss. We decree that violators of this law shall be punished by a fine of 5 o pounds of gold. Among them are to be considered the members of your official staff if they suggest any such disposition or prepare a petition of a claimant."

PLRE II, 336-339. 
1. Adluvionum, quae contingere solent in praediis quae ripis quorundam fluminum terminantur, ea natura est, ut semper incerta possessio, incertum sit eius dominium quod possessori per alluvionem adcrescit. Nam quod hodie possidemus nonnumquam altero die vicini fundi dominio in alteram fluminis ripam translatum adquiritur nec tamen apud quem adcrescit semper remanet adquisitum, sed plerumque redit ad priorem dominum cum augmento, saepenec ad posteriorem manet nec ad priorem redit, sed in harenam fluminis inundatione dissolvitur.

2. Ideo suggestionem tui culminis admittentes non Aegyptiis solis nec de Nili tantum adluvionibus loquimur, sed quod salubre est orbi terrarum atque omnibus provinciis promulgamus. Et ea, quae per adluvionem possessoribus adquiruntur, neque ab aerario vendi neque a quolibet peti nec separatim censeri vel functiones exigi hac perpetuo lege valitura sancimus, ne vel adluvionum ignorare vitia vel rem noxiam possessoribus videamur indicere.
1. The nature of alluvial lands, which customarily arise in the case of the landed estates that are bounded by the banks of certain rivers, is such that possession of such lands is always uncertain, and the ownership is uncertain of that land which accrues to a landholder through alluvion. For what we possess today is sometimes transferred the next day to the other bank of the river and to the owner ship of a neighboring farm and is thus acquired by such farm. However, such land does not always remain in the possession of the person to whom it accrued and by whom it was acquired, but it often returns with an increase to the former owner. Often it does not remain with the later owner nor return to the former owner, but it is dissolved by the inundation of the river into the sands of the river.

2. Therefore We accept the report of Your Eminence, and We are not speaking of Egypt alone or only about the alluvial lands of the Nile, but what We promulgate is salutary for the world and for all the provinces. We sanction by this law which shall be valid forever that those lands that are acquired by landholders through alluvion shall neither be sold by the treasury nor petitioned for by any person whatever, and they shall not be separately assessed nor shall compulsory public services be exacted of them. Thus We shall not appear to disregard the disadvantages of the alluvial lands nor to impose a regulation that is hurtful to the landholders. 
3. Similiter nec ea quidem, quae paludibus antea vel pascuis videbantur adscripta, si sumptibus ac laboribus possessorum nunc ad frugum fertilitatem translata sunt, vel vendi vel peti vel quasi fertilia separatim censeri vel functiones exigi concedimus, ne doleant diligentes operam suam agri dedisse culturae nec diligentiam suam sibi damnosam intelligant.

4. Huius legis temeratores quinquaginta librarum auri condemnatione coerceri decernimus. Inter quos habendum est officium quoque tuae sedis excelsae, si aliquid eiusmodi suggesserit disponendum vel si preces instruxerit petitoris, Cyre, parens karissime atque amantissime.

5. Inlustris itaque et magnifica auctoritas tua, suggestione tui culminis hac dispositione non admissa tantum, sed etiam conlaudata, legem hanc edictis propositis ad omnium notitiam perferri praecipiat.

Dat. XI. kal. oct. Constantinopoli, d.n. Valentiniano a. V. et Anatolio vc. conss.
3. In a similar manner, We grant that those lands which appeared formerly to have been assessed as swamps or pasture lands, if they have now been transformed by the expenditures and labors of their possessors to fertility and fruitfulness, shall neither be sold nor petitioned for, they shall not be assessed separately as fertile lands, nor shall compulsory public services be exacted of them. Thus the diligent shall not grieve that they have given their labours to the cultivation of the land, nor shall they learn that their diligence is a loss to them.

4. We decree that rash violators of this law shall be punished by a fine of fifty pounds of gold. Among these must be considered the office staff also of your exalted office if they should suggest that anything of the kind should be arranged or if they should draw up the requests of petitioner, Cyrus, dearest and most beloved Father.

5. Therefore Your Illustrious and Magnificent Authority by posting edicts shall command this law to be brought to the knowledge of all, since because of the report of Your Eminence this regulation was not only admitted but also was lauded.

Given on the eleventh day before the kalends of October at Constantinople in the year of the fifth consulship of Our Lord Valentinian Augustus and the consulship of the Most Noble Anatolius. - September 21, 440. (transl. by C. Pharr) 
This text is full of details for modern readers in a double perspective. On one hand, the constitution shows how the late-antique legislator imagined these peculiar kinds of land, and, in a wider sense, how he described the relation between nature and law. On the other hand, the constitution confirms the emperors' attention to regulating alluvial lands and swamps. Theodosius's II guiding thread seems to be the optimization of the use of these lands, the promotion of new cultivations and the reclamation of unproductive spaces. As for this second aspect, the constitution deals with important issues and consequences for the formation of a Roman political landscape. ${ }^{13}$ Insofar, this paper focuses on the spatial transformation caused by the legislative action of lateantique emperors.

Picturing a Landscape

The constitutions were composed of fixed components: prologue, narration, dispositio, epilogue. ${ }^{14}$ This structure is maintained in the Novellae Theodosianae and the starting point of my text analysis is the exordium of the imperial constitution.

Theodosius sums up his definition of alluvial lands in the following sentence: natura adluvionum, quae contingere solent in praediis quae ripis quorundam fluminum terminantur. According to this, he is referring to estates bordered by the banks of rivers. The peculiarity of these lands is the mobility of the border: flexuosa linea est multiformis, velut arvorum aut ingorum aut fluminum - says another gromaticus. ${ }^{15}$ In fact, the border is subject to the phenomenon of the alluvio, that is the erosion or the growth of the river bank. ${ }^{16}$ These types of

13 In opening a discussion involving the category of political landscape, we should reflect on the significance of these terms. We can assume that the word landscape can be understood as land that humans have modified or build on and that the adjective political refers to the exercising of power of the administrators of Roman institutions.

14 On the structure of the imperial constitution: J. Matthews, Laying Down the Law (New Haven and London 2000), 121-167; E. Romano, 'Constitutiones in cerca di uno stile: lettura della Constitutio Sirmondiana 2', in D. Mantovani (ed.), Le strutture nascoste della legislazione tardo antica (Bari 2019), 267-284. The style of the late antique legislator is also studied in G. Vidén, The Roman Chancery Tradition. Studies in the Language of Codex Theodosianus and Cassiodorus' Variae (Gothenburg 1984).

15 Balb. grom. p. 99.6 (ed. Lachmann).

16 By metonymy, adluvio can indicate the land brought by the river due to its increase: Dig. 7.1.9.4; Dig. 7.1.33.1. 
lands are well described in many sources: $:^{17}$ for example, in the liber colonarius, agri limitati with rivers as their borders - lands which are assigned by measurement and artificial boundaries - but also the agri arcifinii $^{18}$ - lands which are bounded by natural limits. ${ }^{19}$ But even papyri show how the annual flood of the Nile in the Egyptian region caused vast changes to the coastal lands. ${ }^{20}$

The emperor noted that possession was uncertain in lands bounded by riverbanks. Clearly, Theodosius II is not discussing the relationship between alluvial impact and property rights in a technical way. ${ }^{21}$ The exordium instead has a rhetorical purpose. The emperor opens his discourse by describing a situation of legal insecurity: who is the owner of these lands? Then, to communicate more efficiently a feeling of temporariness to the readers, he emphasizes not only spatial precariousness, but also temporal instability. The emperor in fact says that one day is enough to modify the situation that has been created: hodie possidemus nonnumquam altero die vicinifundi dominio in alteram fluminis ripam translatum adquiritur.

Therefore, the instability of the alluvial lands is not considered by the legislator as a natural fact only, but also as a topos, a cleverly constructed description

17 The existence of cultivated land bordering a river is attested in the cities of Faliscus ( $L i b$. colon., ed. Lachmann, p. 217,5), Sutri (Lib. colon., ed. Lachmann, p. 217.17), Veio (Lib. colon., Lachmann, p. 220.13), Aternus (Lib. colon. ed. Lachmann, p. 253.15), Aminternum (Lib. colon., ed. Lachmann, p. 228.4); borders formed by the banks of rivers are also described in Liber coloniarum (ed. Lachmann, p. 253.21; 256.10) and in Casae litterarum (ed. Lachmann, p. $314.8 ; 321.4 ; 326.20 ; 333.23)$.

18 J. Castillo Pascual, 'Ager arcifinius: significado etimologico y naturaleza real', Gerion 11 (1993), 145-151; P. Botteri, 'La définition de l'ager occupatorius', Cahiers du Centre G. Glotz 3 (1992), 45-55.

19 Cassiodorus refers to the same image: Cassiod. Var. 2,32-33. See, A. Giardina, Cassiodoro politico (Rome 2006), 73-99.

20 D. Bonneau, Le fisc et le Nil. Incidences des irregularites de la crue du Nil sur la fiscalité fonciere dans l'Egypte grecque et romaine (Paris 1971); K. Blouin, Triangular landscapes. Environment, Society, and the State in the Nile Delta under Roman Rule (New York 2014).

21 If we compare this part of the constitution to the Gaius' doctrine of accretion, we understand how far apart the two texts are: Gai. inst. 2.70-71 Sed et id, quod per alluuionem nobis adicitur, eodem iure nostrum fit: per alluuionem autem id uidetur adici, quod ita paulatim flumen agro nostro adicit, ut aestimare non possimus, quantum quoquo momento temporis adiciatur: hoc est, quod uolgo dicitur per adluuionem id adici uideri, quod ita paulatim adicitur, ut oculos nostros fallat. Itaque si flumen partem aliquam ex tuo praedio resciderit et ad meum praedium pertulerit, haec pars tua manet. Transl. by F. de Zulueta: "Alluvial accretions to our land become ours, again by natural law. That is held to be an accretion by alluvion which a river adds to our land so gradually that is impossible to estimate how much is being added at any particular moment; whence the common saying, that an addition is by alluvion if it is so gradual as to be invisible. Accordingly, if a river tears away a piece of your land and carries it down to mine, that piece remains yours." 
of a landscape. Theodosius II was not discussing a specific situation: he did not give details of places or he did not mention any particular rivers. The emperor was speaking abstractly of the situation of alluvial lands.

If we want to understand if this narration was written by Theodosius's chancery itself or is referring to a previous text, we can match Theodosius's words to a chapter of the book written by Agennius Urbicus - the same writer already mentioned before - who was paraphrasing a previous land surveyor, Frontinus:

Controversia est status effectivi. Efficitur enim subinde, et per tempora mutatur. In hac controversia plurimum sibi vindicat ius ordinarium; agitur enim de eo solo quod alluat flumen, et subtiles introducuntur quaestiones, an ad eum pertinere debeat cui in altera ripa recedente aqua solum crevit; hic qui aliquid agri sui desiderat, transire, et possidere illud debeat quod flumen reliquit. Nisi quod illud subtilissime profertur, quod is solum amisit, non statum transire in alteram ripam, sed abductum esset et elotum; et illud contra, vicinum longe dissimilem agrum habere, quod hic forte cultum et pingue solum amiserit, apud illum autem harenae, lapides et limum abluvio invectum remanserit. Illud praeterea, quod finem illis semper aqua fecerit, et nunc quoque facere debeat. ${ }^{22}$

The investigation of disputes was a significant part of a surveyor's activities, and Agennius is opening his tract on disputes about alluvial land. ${ }^{23}$ His exordium refers to the many legal problems associated with rivers. An example of these complicated questions is the change in a river's course; it is very difficult to establish who is the owner of the lands while the river ran his old course, and it is unclear if the landholders, who lost part of their property to the changed course of the river can now cross the river and farm the land that was created on the opposite side of the bank of the river. In this case, Agennius explains that the volatility of the course of the river must be considered, because the

22 Agenn. 82.7-21 (transl. by B. Campbell): "The dispute concerns the soil that a river deposits, and complex questions are thereby produced, namely, whether it should belong to the person on the opposite bank whose land has been augmented on the retreat of the river water, or whether the men who lost some of his land should cross over and take possession of that soil that the river deposited. But against this is raised a very subtle point, that namely, that the soil that one man lost does not immediately cross over to the other bank, but is removed and washed away (by the river). And, on the other hand, the neighbour receives a very different type of soil, because, while the former lost soil that perhaps cultivated and fertile, the latter was left with a residue of sand, stones, and mud washed up by the flood water."

23 P. Castillo Pascual, 'Die Controversia de alluvione bei Gromatikern und Juristen', eTopoi. Journal for Ancient Studies, 2 (2012-2013), 1-23. 
soil deposited in a field stops to exist because the waters of the river have already taken away.

Agennius is stressing the instability of this natural landscape, which can change its aspect very quickly. He wants to convey the idea that it is precisely the instability of the land that causes uncertainty in the world of law. The sudden and indeterminable change of nature gives rise to disputes between private individuals.

If we compare the text of Agennius to the Novella, we might suppose that they are using the same image for alluvial lands. A common aspect between these texts is that Agennius and Theodosius put this description in an introductory part of their discourse: both want to communicate that the condition of the lands is temporal. Both introduce their discourse by referring to the legal questions that the alluvio poses: the first problem to solve is "who is the owner of the land deposited by the river"? Also, both describes the same phenomenon, even if the gromaticus is more precise than the chancery: the land that a river adds to the fields near its bank can augments the territory of the estate on the side on which the addition takes place, but after a short period the same addition can be removed by the flowing of the river.

All these elements could point to a relationship between the two texts. At the moment, I cannot say if the chancery is relying on the text of Urbicus, who probably lived a century before, but it should be clear that they are imagining alluvial lands by referring to the same concept.

\section{$2 \quad$ Imperial Regulation on Alluvial Lands}

But why is Theodosius II depicting the intrinsic instability of the alluvial lands to change? The emperor wanted to strengthen the sense of certainty of his decision, because he was the only one who could regulate what was until now without rule. ${ }^{24}$

Theodosius II enacted that alluvial lands were not to be sold by the treasury nor petitioned for by anyone, and they should not be separately assessed nor should compulsory public services be exacted of them. The emperor also specified that his decision was to be applied not only to the province of Egypt, but to all the territories of the empire. ${ }^{25} \mathrm{~A}$ first reading of the Theodosian provision

\footnotetext{
24 G. Bassanelli Sommariva, L'imperatore unico creatore ed interprete delle leggi e l'autonomia del giudice nel diritto giustinianeo (Milan 1983); S. Puliatti, Il diritto prima e dopo Costantino, in Costantino I (Rome 2013), 599-613.

25 Nov. Theod. 20: non Aegyptiis solis nec de Nili tantum adluvionibus loquimur, sed quod salubre est orbi terrarum atque omnibus provinciis promulgamus (We are not speaking of
} 
could suggest that the emperor considered the uncertainty of the condition of alluvial lands and therefore established that these should not be taxed. Theodosius II would thus have innovated the previous regime: in 402, addressing the case of the inundations of the Nile, Arcadius on one hand imposed taxation on the increase of properties caused by the river an, on the other hand he reduced the tax levy for those who suffered a decrease in land. ${ }^{26}$ However, the provision of Theodosius implemented a wider protection, given that alluvial lands were also to be exempted from the cadastre ${ }^{27}$ and could not have been confiscated by the fiscus $^{28}$ or petitioned for by private parties.

Egypt alone or only about the alluvial lands of the Nile, but what We promulgate is salutary for the world and for all the provinces.)

26 Cod. Iust 7.41.2 Impp. Arcadius, Honorius et Theodosius AAA. Caesario pp. Hi, quos inundatio Nili fluminis redsidit ditiores, pro terris quas possident tributorum praestationem agnoscant. Et qui suum deplorant patrimonium imminutum, alieno saltem functionis onere liberentur et nostrae serenitatis largitate defensi, locorum etiam possessione contenti, pro agitandi census examine respondeant devotioni. D. III id. Iun. Theodosio A. et Rumorido conss. (a. 402). Transl. by B.W. Frier: "Persons whom the inundation of the river Nile makes richer must pay tribute for the land which they possess. But those who lament the diminution of their property should at least be relieved from the burden of an obligation owed by another, and, protected by bounty of Our Serenity and content with the land they possess, they should devotedly pay their tribute according to the adjustment made." On this constitution, see, Barbati 2014, op. cit. (n. 10), 366; Tarozzi 2018 op. cit. (n. 10), 5o. Actually, traces of a provision similar to the one of Theodosius II could be found in an edict of prefect Tiberius Iulius Alexandrus (ogIs 669), dated to July 6, 68 BCE. The edict (ll. 59-62) established that in the region of Alexandria, called Menelaite, the growth of land caused by the flooding phenomena of the Nile $(\pi \rho \circ \sigma \varepsilon v \dot{\eta} \mu \alpha \tau \alpha)$ maintained the same privileges enjoyed by the lands to which they were added ( $\dot{\alpha} p \chi \alpha \dot{\alpha} \alpha \gamma \hat{\eta})$. In other words, alluvial lands were exempted from taxation and could not be included in the land register, on which see, G. Chalon, L'édit de Tiberius Julius Alexander. Ètude historique et exégétique (Olten and Lausanne 1964); K. Blouin, 'Représentation et gestion des "atterrissements alluvionnaires" $(\pi p \circ \sigma \varepsilon \varepsilon v \eta \dot{\mu} \alpha \tau \alpha)$ dans l'Égypte hellénistique et romaine', in Y. Tristant and M. Ghilardi (eds.), Landscape Archaeology. Egypt and the Mediterranean World (Cairo 2018), 137-150. However, considering the content of Cod. Iust. 7.41.2, it is very difficult to affirm that the continuity of the regulation of alluvial lands in Egypt was maintained until the constitution of Theodosius II. A plausible indication of a change in imperial legislation may be taken from what the legislator says in the principium of the constitution. In fact, the emperor says that "something is always presented ... for correction" (semper nobis aliquid porrigitur emendandum). In this sentence, Theodosius II could allude to the decision to correct the legal regime of alluvial lands introduced by Arcadius.

27 The edict of Tiberius Iulius Alexandrus and the papyri show that the alluvial lands in Egypt were inscribed in the cadastre in order to be taxed, see Chalon 1964 op. cit. (n. 26); Blouin 2018 op. cit. (n. 26). The same situation, however, is pictured in the Tabula Veleatis see M.P. Pavese Fundus cum vadis et alluvionibus: gli incrementi fluviali fra documenti della prassi e riflessione giurisprudenziale romana (Rome 2004), 56 .

28 P. Thonemann, The Maeander Valley. A Historical Geography from Antiquity to Byzantium (Cambridge 2011), 312 supposes that the real concern of Theodosius is to not make periodic 
The emperor seemed to make a reference to a situation of fact as a precondition for his decision: someone had occupied ${ }^{29}$ some lands added by sedimentation or deposited by a river, ${ }^{30}$ with the intention to hold them as property. Of course, the emperor knew that the land addition would have attracted also various other interests: the fiscus would have considered them as belonging to no one (bona vacantia), ${ }^{31}$ and thus would have tried to confiscate them; privates parties would have petitioned to have these lands assigned to them.

The emperor granted the occupants something equivalent to effective legal ownership ${ }^{32}$ and he gave them a very large degree of legal protections, like the prohibition for the fiscus to sell these lands and the prohibition for privates to make petitions. This aspect was clearly understood and affirmed in the Basilica by the byzantine jurists who defined the occupants $\delta \varepsilon \sigma \pi \sigma^{\prime} \tau \alpha_{\mathrm{l}}{ }^{33}$

revisions to the cadaster. B. Campbell, Rivers and the Power of Ancient Rome (Chapel Hill 2012), 115 proposes that Theodosius aimed to prevent any financial exaction on the land until it had become productive even if the constitution doesn't show it clearly.

29 See J. Cujas, Paratitla In Libros IX Codicis Iustiniani Repetitae Praelectionis (Paris 1579), 166; Thonemann 2011 op. cit. (n. 28), 311. For C.A. Cannata, Possessio, Possessor, Possidere nelle fonti giuridiche del basso impero. Contributo allo studio del sistema dei rapporti reali nell'epoca postclassical (Milan 1963), 159 the word possessor specifies the condition of the owner after the abolition of the different regimes of property.

30 The Interpretatio of Nov. Theod. 20 in the Breviarium Alaricianum instead considers a specific situation: si fluvius alveum suum paulatim in aliam partem contulerit, terram ille acquirat, cuius finibus spatium terrae dignoscitur contulisse. The Interpretatio refers to the alvei mutatio, that is when a river transfers its bed into another part of the landscape. In this case - says the late antique author - the land now belongs to the person who owns the land to which the land was added. However, the constitution of Theodosius seems to be more abstract and used the expression ea, quae per adluvionem possessoribus adquiruntur in order to indicate all the natural manifestations of adluvio. See also, Barbati 2014 op. cit. (n. 10), 368.

31 I.D. Ritter, $n$. k. ad De alluvionibus, in Codex Theodosianus cum perpetuis commentariis Iacobi Gothofredi, vi (Leipzig 1743), 34; P. Voci, Nuovi studi sulla legislazione romana del tardo impero (Padua 1989), 198. More generally on the fiscus, R. Delmaire, Largesses sacrées et res privata. L'aerarium impérial et son administration du $\mathrm{IV}^{e}$ au $\mathrm{VI}^{e}$ siècle (Rome 1989).

32 A different interpretation of the constitution is proposed by Barbati 2014 op. cit. (n. 10), 366. The scholar believes that in Roman law there was no doubt that the landlords of the land near the river became the owner of alluvial land. However, the beginning of the constitution - and the texts of the gromatici - would seem to affirm the opposite: incertum sit eius dominium quod possessori per alluvionem adcrescit. In my opinion, it is precisely the uncertainty over the ownership of alluviones that drives the legislator to intervene.

33 Bas. 50.16.3 in H.J. Scheltema and N. van der Wal (eds.), Basilicorum libri LX, A, 6

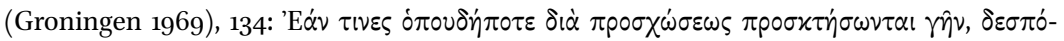

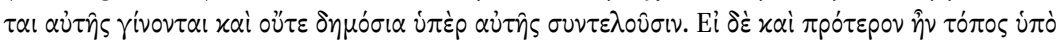


If so, the constitution could represent one of the very few testimonies of how alluvial lands were defined in Roman history. For a parallel, one must go back to the Principate and to an enactment of Diomitanus, the existence of which is recorded in many writings of land surveyors. ${ }^{34}$ The constitution of Domitianus could be connected to subseciva, which are the land that remained unallocated in the centuria. We know also that subseciva included land that was not allocated in the distribution on the banks of the river (which are res publica), and that this land is considered of little value and very difficult to cultivate. ${ }^{35}$

Even if the text of the constitution of Domitianus is not known in its entirety, we learn that the emperor freed the people that had occupied subseciva in Italy from losing these lands. In fact, past emperors like Vespasianus exploited the uncertainty of the legal status of these lands and claimed them and forced their cultivators to surrender or to buy them as they were property of the Roman state. ${ }^{36}$

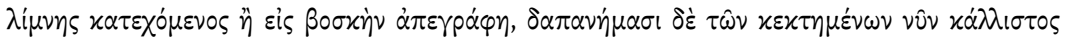

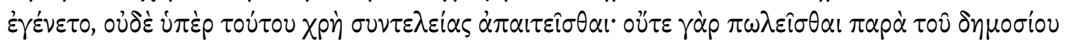

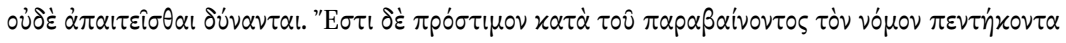

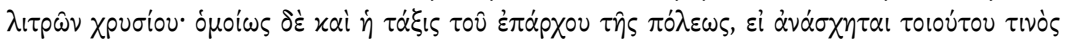

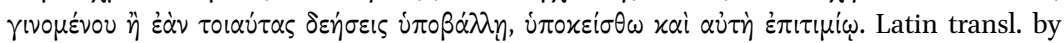
K.W.E. Heimbach, Basilicorum libri LX, 5 (Leipzig 1850), 84: Si quidam ubicunque per alluvionem acquisierint terram, domini eius tiunt, neque publica pro ea conferunt. Sed etsi ante locus fuit a palude obrutus, aut in pastionem descriptus, sed impensis possessorum nunc optimus est factus: nec pro eo collationes exigi debent: neque enim vendi a fisco, nec peti possunt. Est autem poena adversus transgressorem huius legis quinquaginta librarum auri. Similiter etiam officium Praefecti urbis, si quid huiusmodi patiatur fieri, aut si tales preces subiiciat, subiaceat etiam ipsum mulctae.

34 Svet. Dom. 9.7; Front. grom. p. 41.24-25 (ed. Lachmann); Hyg. grom. p. 97.4-5 (ed. Lachmann); Sic. Flacc. grom. p. 128.1-2 (ed. Lachmann).

35 On the link between subseciva and rivers: J.-G. Gorges, 'La vie au bord de l'eau en moyenne vallée du Gaudiana sous le Haut-Empire', Caesarodunum 41-42 (2007), 43-74; G. Chouquer, 'Les fleuves et la centuriation: l'apport des catégories gromatiques', Jus 2 (2014), 379-406; J. Hettinger, 'Neues zum Kataster von Lacimurga. Die Darstellung der subseciva entlang des Ana', Chiron 47 (2017), 189-212; B. Brugi, Le dottrine giuridiche degli agrimensori romani comparate a quelle del Digesto (Verona and Padua 1897), 395; Pavese, 2004 op. cit (n. 27), 93-97.

36 Abusive occupations of public land - such as the one which is close to rivers - have been attested in sources since the Republican age. Herodianus (Hdn. 2.7) describes the occupation of the ager publicus by the most important families in Italy. Tacitus (ann. 14.18) reports the same situation in the provinces. For a particular hypothesis of abusive occupation concerning the territory of Lusitania, near the river Ana, see Brugi 1897 op. cit. (n. 35), 395; Hettinger 2017 op. cit. (n. 35), 189-212. 
The constitution of Domitianus could be connected to the alluvial lands, because it might suggests that the emperor affirmed the rights of the cultivators of the river banks, who seized the subseciva. ${ }^{37}$ Even nearly four hundred years later, and in a very different context, Theodosius II could, probably, have made the same choice to allocate the lands that were subject to the flooding of the rivers to those who had occupied them.

At first glance, modern scholars might argue that the emperor made a concession, shown by the motivation of his decision: "Thus We shall not appear to disregard the disadvantages of the alluvial lands nor to impose a regulation that is hurtful to the landholders". But the emperor explicitly enacts this law in perpetuity (hac perpetuo lege valitura sancimus). Therefore, the constitution was not be a act of liberality, but is a perpetual permission to the occupants to use and cultivate adluviones.

Of course, one of the consequences of the imperial decision would have been a great exploitation of alluvial lands to prevent the abandonment of these areas by the population. The incentive to cultivate alluvial land would in fact have increased the production of agricultural materials able to provide for the population's livelihood. In addition, the exemption from taxation would have resulted in a higher income from the land.

The same objective seems to have been pursued when, after considering the flood lands, Theodosius II refers to swamp lands ${ }^{38}$ and pastures ${ }^{39}$ in the second paragraph of the constitution.

Just like alluvial land were occupied to be converted in plantations, swamps and pasture lands were used for breeding livestock. Therefore, Theodosius II decreed that the regulation introduced for the alluvial lands should be applied

37 According to another interpretation of Domitian's edict, the emperor only guaranteed possession of the lands, but did not attribute the property: L. Solidoro Maruotti, Studi sull'abbandono degli immobile nel diritto romano. Storici, giuristi, imperatori (Naples 1984), 245-249; Maganzani 1997 op. cit. (n. 6), 368.

38 On marshy lands see G. Traina, 'Paesaggio e "decadenza”: la palude nella trasformazione del mondo antico', in A. Giardina (ed.), Società romana e impero tardo antico, III (Rome 1986), 711-730; 905-917; G. Traina, Paludi e bonifiche del mondo antico. Saggio di archeologia geografica (Rome 1988); G. Traina, L'immagine imperiale delle paludi pontine, in La valle pontina nell'antichità. Atti di convegno (Rome 1990), 39-44.

39 It is not surprising that the legislator connected these kinds of land. In the context of pasture, the late-antique writer Palladius Rutilius Taurus Aemilianus tells us that agripalustri were a perfect environment where pigs could be reared: see Pallad. 3.26.3. 
to them as well. The emperor recognised the right of property of those people who transformed unproductive lands into fertile and fruitfulness ones by their expenditures and labours. Theodosius II rewarded diligence and effort to occupy these territories, which have always been considered infertile and fruitless. ${ }^{40}$

The emperor furthermore decreed that violators of his law should be punished with a fine of fifty pounds of gold to ensure that these lands did not become the object of the desire of both private individuals and imperial officials. He also ordered that the office staff of the Pretorian prefect should be considered as transgressors, if they should suggest that any administrative procedures like taxation or inclusion in the cadastre should be arranged or if they should draw up the requests of petitioner. ${ }^{41}$

\section{$4 \quad$ A Theodosian policy on Use and Development of Lands}

The Novella attests to the keen attention that Theodosius II paid to the recovery of lands that otherwise would have remained untapped. It can perhaps be said that Theodosius II had planned to implement a policy of land exploitation throughout his reign. The Novella 20 is therefore the first piece of a more complex and rich legislative mosaic. At least two other provisions, which I will briefly mention, must be added.

The first one is the Novella Theodosiana 24 , addressed to the magister officiorum Nomo. It concerns a corrupt solicitation and the parcel of land that was given to the border militia (limitanei). ${ }^{42}$ In the fourth paragraph of this long constitution, Theodosius recognised to the border militia's right of ownership of the fields at the border, including the swamp lands, which, according to the ancient regulation, the militia was accustomed to care for and to cultivate for their own profit. The precondition imposed by the legislator in order to protect

40 The same justification was invoked by Cassiodorus while answering to the Senate (Cass., Var. 2,32) and to Decius, a patricius, who was recognized as owner the of the palus Decennonii, Cass, Var 2,33: Aequum est enim ut unicuique proficiat labor suus, et sicut expendendo cognoscit incommoda, ita rebus perfectis consequatur augmenta. See Giardina 2006 op. cit. (n. 19), 81.

41 Novell. Theod. 20.4.

42 On limitanei, B. Isaac, 'The meaning of limes and limitanei in ancient sources', in: B. Isaac (ed.), The Near East Under Roman Rule. Selected Papers (Leiden 1998), 345-387; L. Minieri, Excepta annona limitaneorum. Una riflessione sulla condizione dei limitanei in età tardoantica, in Atti dell'Accademia Romanistica Costantiniana. XXI. Frontiere della romanità nel mondo tardo antico. Appartenenza, contiguità, alterità tra formazione e prassi (Spello, 18-2o settembre 2013) (Naples 2016), 333. 
this right is that such fields are to be cultivated by limitanei at the time of the constitution..$^{43}$

The emperor is ready to defend the right of property of the limitane $i$ as long as they continue to cultivate the land: the risk that the emperor wants to avoid is the abandonment of lands that, if cultivated, are able to guarantee the sustenance of many people in these remote areas of the empire.

The second one is the Novella Theodosiana $26,{ }^{44}$ addressed to the praetorian prefect of the Orient Hermocrates, titled DE RELEVATIS, ADAERATIS, VEL

43 Novell. Theod. 24.1.4 (=Cod. Iust. 11.6o.3):Imperatores Theodosius, Valentinianus AA. Nomo mag. off. Agros etiam limitaneos universis cum paludibus omnique iure, quos ex prisca dispositione limitanei milites ab omni munere vacuos ipsi curare pro suo conpendio atque arare consueverant, et si in praesenti coluntur ab his, firmiter ac sine ullo concussionis gravamine detineri, et si ab aliis possidentur, cuiuslibet spatii temporis praescriptione cessante ab universis detentoribus vindicatos isdem militibus sine ullo prorsus, sicut antiquitus statutum est, conlationis onere volumus adsignari: in his etiam contra eos, qui praeceptionibus nostris obviam venire temptaverint, eadem poenarum acerbitate, quae adversus ducum aviditatem prolata est, valitura. Nam si quis forte, quod minime audere debuerat, emptionis titulo memorati iuris possidet praedia, conpetens ei actio contra venditorem intacta servabitur. D. Prid. Id. Sept. Constantinopoli Maximo II et Paterio conss. (a. 443). Transl. by C. Pharr: "It is Our will that the fields of the borders also, together with all the swamp lands and every right of ownership, which according to the ancient regulation the border militia themselves were accustomed to care for and to cultivate for their own profit, free from every compulsory public service, shall be held by them firmly and without any annoyance of extortion, if such fields are being cultivated by them at the present time. If such fields should be possessed by other persons, the prescription of any space of time whatever shall cease for all such holders, and it is Our will that such fields shall be vindicated to the aforesaid soldiers and shall be assigned to them without any burden at all of tax payment, as was anciently established. In such cases, the same severity of punishment as was published against the greed of the dukes shall be valid against those persons who attempt to contravene Our regulations. For if any person perchance should obtain possession of the landed estates of the aforesaid ownership under the title of purchase, a thing which he must not dare to do, the right of action which is available to him shall be preserved intact against the seller." On this constitution see, S.J.B. Barnish, 'Taxation, land and barbarian settlement in the Western Empire', BSR 54 (1986), 186 n. 147; P. Tedesco, 'Sortes Vandalorum: forme di insediamento nell'Africa post-romana', Y. Rivière and P. Porena (eds.), Expropriations et confiscations dans l'Empire tardif et les Royaumes Barbares (Rome 2012), 207; W. Kaiser, 'Spätantike Rechtstexte in agrimensorischen Sammlungen', ZSav 130 (2013), 318-321.

44 Novell. Theod. 26.4 (= Cod. Iust. 11.59.17): Imperatores Theodosius et Valentinianus AA. Hermocrati pp. Verum et si quis ex auctoritate nostri numinis vel praeceptis amplissimae praefecturae de fundis patrimonialibus steriles sub certi canonis pollicitatione suscepit, firmiter eum volumus possidere sub eiusdem tantum canonis solutione, quem nostrae maiestatis auctoritas aut praeceptum magnificae tuae sedis per annos singulos solvendum esse praescripsit, nullamque eos discriptionem aut adiectionem aut innovationem in posterum sustinere, quoniam nimis absurdum est eos, qui nobis hortantibus aut magnifica praefectura fundos inopes atque ieiunos magno labore inpenso aut exhausto patrimonio vix forte 
DONATIS POSSESSIONIBUS. ${ }^{45}$ Theodosius decreed that if someone were to receive infertile lands from patrimonial farms, with the promise to pay a fixed tax, he would firmly possess them. The emperor also stated that there would be no tax increases for these lands. But the motivation that the legislator presented is important: it is too absurd that those people, who are neither able to improve infertile and unproductive farms with manpower and high expenses nor maintain the farm relying only on their own capital, should take on an unexpected burden. Theodosius wants in every way to favour the cultivation of infertile lands, to the point of committing himself to not increase the tax burdens on agri deserti. The emperor considers himself compensated by the work and the hardships of those who are cultivating the land, the lost revenue from these lands, once made fertile.

All these constitutions, including the Novella on alluvial lands and marshy lands, were issued within a few years, from 440 to 444 . The intensity with which Theodosius intervenes in the problem of land exploitation therefore seems to suggest a focussed policy. The emperor aimed at improving the conditions not only for maintaining the cultivated land but also for extending the productive agricultural areas, while using different instruments and taking into account the different local circumstances.

These provisions also testify to the fact that generations of men fought the harshness of nature with work and daily fatigue, while at the same time the hardest battles against the invasions of barbarians appeared on the frontiers of the empire.

meliorare potuerint, utpote deceptos inopinatum onus sustinere illudque velut quadam circumventione deposci, quod si se daturos praescissent, fundos minime suscipere aut etiam colere paterentur. D. XII K. Dec. Constantinopoli Theodosio a.XVIII et Albino conss. (a. 444). Transl. by C. Pharr: "But if any person by the authority of Our Divinity or by the regulations of the Most August prefecture should receive sterile lands from Our patrimonial farms, under the promise of paying the fixed regular tax, it is Our will that he shall possess them firmly by the payment of the aforesaid regular tax only, which the authority of Our Majesty or the regulation of your Magnificent office has prescribed must be paid each year. Such lands shall sustain no tax assessment or addition or innovation in the future, since it is too absurd that those persons who by Our urging and that of the Magnificent prefecture could perhaps scarcely improve the barren and unproductive farms by great labor and expense or even by exhausting their patrimony, should accept a burden that was unexpected, inasmuch as they had been deceived, and that this burden should be demanded of them, as if by some circumvention." On this constitution see, S. Tarozzi, 'Riforma dello Stato e gestione della terra. La questione degli agri deserti nella prospettiva dei Codici tardo antichi. Alcuni spunti di riflessione', MEFRA 125 (2013), URL: https:// journals.openedition.org/mefra/1861 (last accessed on March 26, 2021).

45 Landholdings relieved of taxes or having their taxes commuted into money or having been conferred as grants. 


\section{$5 \quad$ Conclusion}

In conclusion, the analysis of the text of the Novella 20 by Theodosius II has demonstrated the following points:

Firstly, the emperor constructs an image of alluvial lands that does not refer to any specific situation. The emperor then creates an abstract image, almost an ideal, that may find common aspects with the writings of the surveyors, in particular Agennius Urbicus. The description corresponds to what happens in nature, but at the same time the legislator modifies the description of natural reality according to the function it must perform in his provision.

Secondly, the emperor describes the instability of alluvial lands and the legal consequences of this uncertainty. The emperor therefore wants to put an end to doubts over the ownership of alluvial lands and establishes that the occupants shall obtain the right of ownership. This also holds true for the cultivators of marshes. This interpretation of the imperial constitution is important because it provides new important information on the regulation of alluvial lands in Late Antiquity, hitherto neglected by historiography.

Thirdly, through Novella 20, Theodosius II primarily intended to guarantee legal - and therefore political - stability in the regions concerned by his decrees. He wanted on one side to affirm the rights of riparian possessores, who seized alluvial lands and swamps, and on other side to prevent migration and rural depopulation ( $\dot{\alpha} \nu \alpha \chi \dot{\omega} p \eta \sigma \varsigma)$. Certainly, these two aspects are strictly connected because securing ownership of alluvial land is one important supporting measure for the demographical stability of the countryside. But the enactment of Theodosius II is not the only constitution in which he wants to regulate land management. In other subsequent provisions, like Novella 24 and Novella 26 , issued within a few years, the emperor himself demonstrates a very keen attention to the recovery of less fertile lands and he decides to reward the work of those who have cultivated them. 